\title{
Comparison of propofol and ketofol in minor gynecologic interventions
}

\section{Küçük jinekolojik girişimlerde propofol ve ketofol anestezisinin karşılaştırılması}

Yasemin Işık ${ }^{1}$, Zehra Kurdoğlu², Uğur Göktaş ${ }^{3}$, İsmail Katı ${ }^{4}$, Dilara Sözen ${ }^{5}$

\begin{abstract}
Objective: Outpatient anesthesia requires a safe anesthetic method and an anesthetic agent that provides a rapid anesthesia depth and hemodynamic stability. To provide an uneventfully recovery, the anesthetic must also be rapidly metabolized, and its metabolites should not accumulate in the body. This study compared sedoanalgesia effects, recovery times, postoperative complications, Modified Aldrete Scale, Visual Analog Scores, and patient and surgeon satisfaction between propofol and ketofol, administered as anesthetics during the probe curettage procedure.
\end{abstract}

Methods: A total of 60 female patients included in the study. Group P was administered $2 \mathrm{mg} / \mathrm{kg}$ of propofol and a $1 \mu \mathrm{g} / \mathrm{kg}$ intravenous bolus of fentanyl for induction and $100 \mu \mathrm{g} / \mathrm{kg} / \mathrm{min}$ of propofol for maintenance. Group K was administered a $600 \mu \mathrm{g} / \mathrm{kg}$ IV bolus of ketofol for induction and $100 \mu \mathrm{g} / \mathrm{kg} / \mathrm{min}$ of ketofol for maintenance. Additional fentanyl $(50 \mu \mathrm{g})$ was administered to Group P, and $25 \mu \mathrm{g} /$ $\mathrm{kg} / \mathrm{min}$ of ketofol was administered to Group K according to autonomic and hemodynamic responses.

Results: Demographic data of the 2 groups were similar. A significant decrease in hemodynamic values was detected in patients in Group P after induction. No change in these values was detected during or after induction in Group K. The additional analgesia requirement was $66.6 \%$ in Group P. Nausea was detected in 2 patients in Group K. Additionally, hallucination was detected in 2 patients in Group K. Patient and surgeon satisfaction were complete in both groups.

Conclusion: According to our findings, ketofol anesthesia may be a good option in uterine curettage, patients recover quickly and comfortably, and ketofol both provides sufficient analgesia for the minor surgical intervention and reduces complications. J Clin Exp Invest 2015; 6 (3): 244249

Key words: Ketofol, propofol, sedo-analgesia, uterine curettage

\section{ÖZET}

Amaç: Günübirlik anestezi, hemodinamik stabiliteyi koruyacak ve anestezi derinliğini hızla sağlayacak bir anestezik ajan ile güvenli bir anestezi metodu gerektirir. Sorunsuz bir uyanma sağlamak için anestezik ilaçlar hızla metabolize olmalıdır ve metabolitleri vücutta birikmemelidir. Bu çalışma da; probe küretaj işlemi uygulanacak hastalarda, propofol ve ketofol anestezisinin sedoanaljezik etkisine, uyanma zamanına, postoperatif komplikasyonlara, Modifiye Aldrete Skalasına, Visüel Analog Skoruna, hasta ve cerrah memnuniyetine bakmayı amaçladık.

Yöntemler: Çalışmaya 60 kadın hasta alındı. Grup p'ye indüksiyonda intravenöz $2 \mathrm{mg} / \mathrm{kg}$ propofol ve $1 \mu \mathrm{g} / \mathrm{kg}$ fentanyl uygulandı. İdamede propofol $100 \mu \mathrm{g} / \mathrm{kg} / \mathrm{dk}$ ile devam edildi. Grup K'ya ise indüksiyonda intravenöz 600 $\mu \mathrm{g} / \mathrm{kg}$ ketofol ve idamede $100 \mu \mathrm{g} / \mathrm{kg} / \mathrm{dk}$ ketofol verildi. Otonomik ve hemodinamik cevaplara göre Grup P'ye $50 \mu \mathrm{g}$ fentanyl, Grup K'ya ise $25 \mu \mathrm{g} / \mathrm{kg} / \mathrm{dk}$ ketofol ek doz yapıldı.

Bulgular: Her iki grupta demografik veriler benzerdi. Grup P'de indüksiyondan sonra hemodinamik parametrelerde belirgin bir düşme görüldü. Grup K'da indüksiyondan sonra hemodinamik parametrelerde herhangi bir değişiklik gözlemlenmedi. Grup P'de ek analjezik gereksinimi \%66,6 idi. Grup K'da 2 hastada bulantı ve 2 hastada halüsinasyonlar görüldü. Hasta ve cerrah memnuniyeti her iki grupta tamdı.

Sonuç: Bizim bulgularımıza göre küçük cerrahi girişim olan uterin küretaj da Ketofol anestezisi iyi bir seçenektir. Hasta da rahat ve hızlı bir uyanma sağlar, ayrıca minör cerrahi girişimlerde analjezi gereksinimini azaltarak postoperatif komplikasyonları da azaltır.

Anahtar kelimeler: Ketofol, Propofol, Sedo-analjezi, Küretaj

\footnotetext{
${ }^{1}$ Department of Anesthesiology and Intensive Care, Izmir Katip Çelebi University, Medical Faculty, Izmir, Turkey

${ }^{2}$ Department of Obstetrics and Gynecology, Ankara Training and Research Hospital, Ankara, Turkey

${ }^{3}$ Department of Anesthesiology and Intensive Care, Yüzüncü Yıl University, Medical Faculty, Van, Turkey

${ }^{4}$ Department Intensive Care, Gazi University, Medical Faculty, Ankara, Turkey

${ }^{5}$ Department of Anesthesiology and Intensive Care, Adana State Hospital, Adana, Turkey
}

Correspondence: Yasemin Işık,

İzmir Katip Çelebi University, Medical Faculty, Dept. Anesthesiology and Intensive Care, Izmir, Turkey Email:yaseminmd@yahoo.com Received: 11.08.2015, Accepted: 10.09.2015

Copyright @ JCEI / Journal of Clinical and Experimental Investigations 2015, All rights reserved 


\section{INTRODUCTION}

Outpatient anesthesia procedures are those in which patients are admitted to the hospital and discharged postoperatively within the same day. The anesthesia applied in these interventions carries risks that are equal to or greater than the surgery for the patient. The tendency for day case surgery has increased with the administration of novel and short-acting intravenous medications and the development of novel monitors. Outpatient anesthesia requires a safe anesthetic method and an anesthetic agent that provides rapid anesthesia depth with hemodynamic stability. To provide an uneventfully recovery, the anesthetic must also be rapidly metabolized, and its metabolites should not accumulate in the body.

Propofol is used for sedation in the induction and maintenance of anesthesia in intensive care units and short surgical interventions. Propofol is administered as an infusion instead of in repeated doses, which prevents dose-dependent respiratory and cardiovascular system depression and provides controlled sedation [1]. Ketamine is preferred for premedication, anesthesia induction and maintenance for purposes of sedation, analgesia and amnesia [2]. Ketamine exhibits similar effects as propofol at sedo-analgesic doses and is safer than propofol. Ketamine in combination with propofol for sedation and analgesia enables the use of lower drug doses, thereby reducing dose-dependent side effects [3].

Although all surgical branches use day case interventions, gynecology and obstetrics use these interventions most often. Probe curettages comprise the vast majority of day case interventions [4]. Many drugs such as opioids, non-steroidal analgesics, nerve blocks, and local anesthetics are used with anesthetics for sedation and analgesia during curettage for gynecological diagnostic and therapeutic purposes [5].

In this study, we aimed to compare sedo-analgesia effects, recovery times, postoperative complications, Modified Aldrete Scale (MAS) scores, Visual Analog Scores (VASs), and patient and surgeon satisfaction between propofol and ketofol anesthetics administered during a probe curettage procedure.

\section{METHODS}

Our study was conducted in an operating room of the Yüzüncü Yıl University Medical Faculty after ob- taining ethics committee approval from Yüzüncü Yıl University (date:15.08.2011, number:02). The study was conducted as a prospective, randomized, single-blind study after obtaining written informed consent from the patients.

A total of 60 female patients between 20 and 50 years old with American Anesthesiology Association (ASA) I-II classifications were included in the study. Patients with acute or chronic hepatic diseases, renal diseases, cardiovascular diseases, psychiatric diseases, central nervous system diseases, alcohol or substance addiction, or hypersensitivity to the drugs planned to be used or patients who did not agree to participate were excluded from the study. The patients, who were not given premedication, were taken to the operating room, and routine monitors were applied for electrocardiography (ECG), non-invasive systolic blood pressure (SBP), diastolic blood pressure (DBP), mean arterial pressure (MAP), and pulse oximetry $\left(\mathrm{SpO}_{2}\right)$. Intravenous (IV) access was obtained on the hand dorsum using a $22 \mathrm{G}$ cannula, and a $0.09 \% \mathrm{NaCl}$ infusion $(4-6 \mathrm{~mL} /$ $\mathrm{kg} / \mathrm{h}$ ) was started. The patients were randomly assigned to two groups according to the order of admission.

Group P was administered $2 \mathrm{mg} / \mathrm{kg}$ of propofol and a $1 \mu \mathrm{g} / \mathrm{kg}$ IV bolus of fentanyl for induction and a $100 \mu \mathrm{g} / \mathrm{kg} / \mathrm{min}$ infusion of propofol for maintenance.

Group K was administered a $600 \mu \mathrm{g} / \mathrm{kg}$ IV bolus of ketofol for induction and maintained with 100 $\mu \mathrm{g} / \mathrm{kg} / \mathrm{min}$ of ketofol (ketofol was prepared as 1:1, $200 \mathrm{mg}$ propofol, $200 \mathrm{mg}$ ketamine $=100 \mathrm{~mL}, \mathrm{cc}: 2$ $\mathrm{mg}$ ).

Additional fentanyl $(50 \mu \mathrm{g})$ was administered to Group P, and $25 \mu \mathrm{g} / \mathrm{kg} / \mathrm{min}$ ketofol was administered to Group K according to autonomic (sweating, eye opening, mouthing, pulling extremities) and hemodynamic (tachycardia, hypertension) responses. Ephedrine (5 mg IV) or atropine (0.5 mg IV) administration was planned to treat hypotension (when the MAP decreases to $20 \%$ of the pre-induction values) and/or bradycardia (heart rate $<50 \mathrm{bpm}$ ) during anesthesia. Oxygen was not provided until $\mathrm{SpO}_{2}$ was $<90 \%$, and $4 \mathrm{~L} / \mathrm{min} \mathrm{O}_{2}$ was provided using a facial mask when $\mathrm{SpO}_{2}$ was $<90 \%$. Sedation levels were evaluated using the Ramsey Sedation Score (RSS) (Table 1), which was maintained between 3 and 4. Heart rate (HR), SBP, DBP, MAP and $\mathrm{SpO}_{2}$ values were recorded before anesthesia induction, at induction, and during anesthesia every $5 \mathrm{~min}$ in $30 \mathrm{~min}$, later every $10 \mathrm{~min}$ during the postoperative period. The patients were transferred to a postoper- 
ative care unit following the surgical procedure, and the RSSs were 7-8. Hemodynamic parameters, recovery time, additional drug requirements, adverse effects, postoperative nausea and vomiting, patient and surgeon satisfaction, MAS scores (Table 2) and VASs were recorded. Lornoxicam $(8 \mathrm{mg})$ was planned for when the VAS score was $\geq 4$, and metoclopramide $(10 \mathrm{mg}$ ) was planned for when nausea and vomiting occurred. Surgeon satisfaction was evaluated as follows: 0 as poor, 1 as insufficient, and 2 as sufficient. Patient satisfaction was evaluated by asking whether the patient was satisfied with the anesthesia method and whether the patient would prefer the same method if a second surgery was needed.

Table 1. Ramsey Sedation Scale

\begin{tabular}{ll}
\hline Score & Clinical condition \\
\hline 1 & Awake and oriented \\
2 & Drowsy, but responds to verbal stimuli \\
3 & Drowsy, but rapidly responds to glabellar tactile stimuli \\
4 & Drowsy, but slowly responds to glabellar tactile stimuli \\
5 & Irresponsive to stimuli \\
\hline
\end{tabular}

Table 2. Modified Aldrete Scale

\begin{tabular}{|c|c|c|}
\hline & 4 Extremities & 2 \\
\hline \multirow[t]{3}{*}{ Activity } & 2 Extremities & 1 \\
\hline & 0 Extremities & 0 \\
\hline & Being able to breathe and cough easily & 2 \\
\hline \multirow[t]{3}{*}{ Respiration } & Dyspnea, superficial, limited respiration & 1 \\
\hline & Apnea & 0 \\
\hline & $\begin{array}{l}\text { Blood pressure } \pm 20 \mathrm{mmHg} \\
\text { preanesthetic period }\end{array}$ & 2 \\
\hline \multirow[t]{3}{*}{ Circulation } & $\begin{array}{l}\text { Blood pressure } \pm 20-50 \mathrm{mmHg} \\
\text { preanesthetic period }\end{array}$ & 1 \\
\hline & $\begin{array}{l}\text { Blood pressure } \pm 50 \mathrm{mmHg} \\
\text { preanesthetic period }\end{array}$ & 0 \\
\hline & Fully awake & 2 \\
\hline \multirow[t]{3}{*}{ Conscious } & Awakening by verbal stimuli & 1 \\
\hline & No response & 0 \\
\hline & At room temperature > $92 \%$ & 2 \\
\hline \multirow[t]{2}{*}{$\mathrm{O}_{2}$ saturation } & $\begin{array}{l}\mathrm{O}_{2} \text { inhalation is required when } \\
\mathrm{SpO}_{2}<90 \%\end{array}$ & 1 \\
\hline & $<90 \% \mathrm{O}_{2}$ saturation & 0 \\
\hline
\end{tabular}

\section{Statistical Analysis}

Descriptive statistics is expressed as the means, standard deviations, and minimum and maximum values. Analysis of variance for repeated measures was performed to determine differences in the characteristics between groups and times. The Duncan multi-comparison test was used following analysis of variance to identify specific differences between groups and times. A p level of $<5 \%$ was accepted as statistically significant, and statistical analyses were performed using SPSS ver.13.

\section{RESULTS}

The demographic data of the 2 groups were similar. No differences were detected between the groups for patient age, ASA classification, RSS score, weight, operative time and recovery time $(p>0.05)$ (Table 3).

Table 3. Patient' demographic data

\begin{tabular}{lcc}
\hline & Group P & Group K \\
\hline Age (year) & $31.29 \pm 12.13$ & $29.66 \pm 11.84$ \\
ASA (I-II) & $25 / 6$ & $26 / 4$ \\
Weight (kg) & $60.9 \pm 11.7$ & $62.9 \pm 9.2$ \\
RSS score & $3.20 \pm 1.24$ & $3.0 \pm 1.26$ \\
Recovery time (min) & 8.83 & 8.87 \\
Operative time (min) & $17.13 \pm 6.4$ & $19.83 \pm 7.5$ \\
\hline
\end{tabular}

Significant decreases were detected in the SBP, DBP, and MAP values of the patients in Group $\mathrm{P}$ after induction compared with the preoperative values. No changes were detected in these values measured during or after induction in Group K. Significant decreases in the SBP, DBP and MAP values were detected after induction in Group P compared with Group K ( $p<0.05)$ (Fig. 1, Fig. 2). The decreases in these values did not indicate a requirement for treatment but were statistically significant.

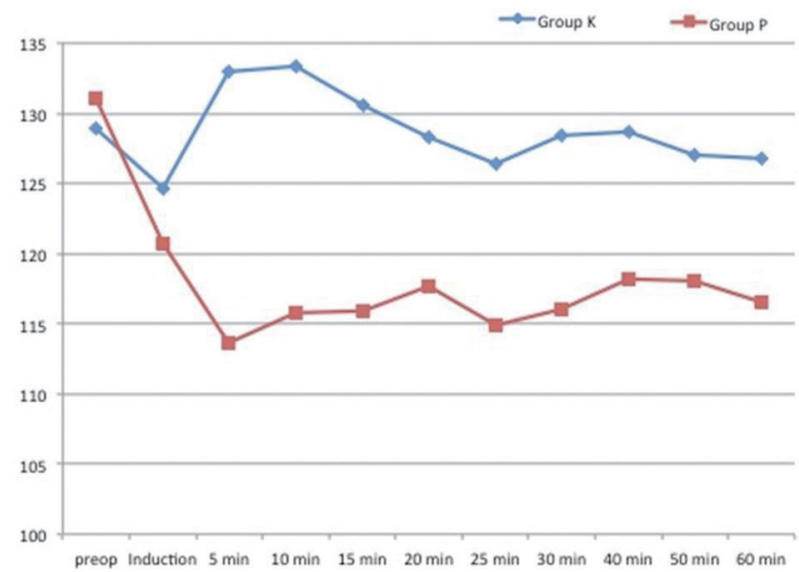

Figure 1. Systolic blood pressure of the groups 


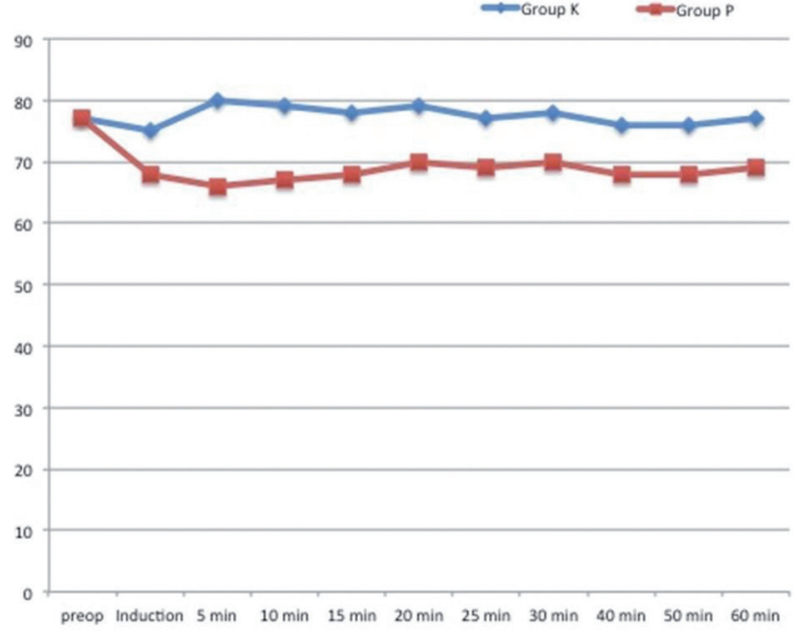

Figure 2. Diastolic blood pressure of the groups

A significant decrease in $\mathrm{HR}$ was observed after induction in Group P, but no change was observed in Group K. A significant reduction in HR was detected in Group P compared with Group K $(p<0.05)$ (Fig. 3). HR did not decrease below 50 in any of the patients.

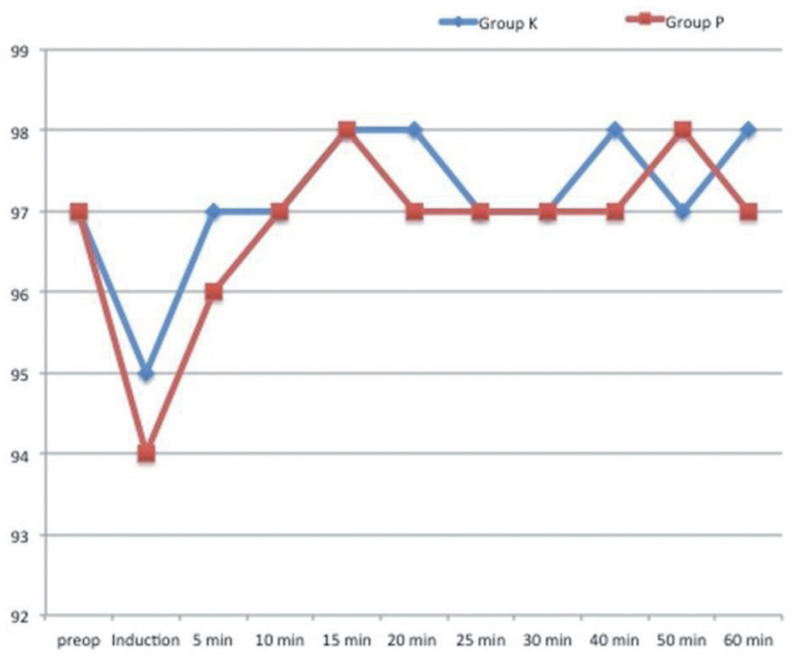

Figure 3. $\mathrm{SpO}_{2}$ values of the groups

Additional analgesia was required in $66.6 \%$ of patients in Group P but was not required in Group $\mathrm{K}$. The additional fentanyl dose was $25 \mu \mathrm{g}$ in Group $P$. Additional analgesia was required significantly more often in Group P than in Group K $(p<0.05)$.

The nausea was detected in two patients in Group K. The nausea and vomiting were not detected in Group P. SpO2 did not drop below $90 \%$ in any of the patients, and $\mathrm{O}_{2}$ was not required. The hallucination was detected in 2 patients in Group K. Patient and surgeon satisfaction were complete in both groups. No significant differences in the VAS and MAS scores in the postoperative care unit were detected between the groups ( $p>0.05)$ (Fig. 4).

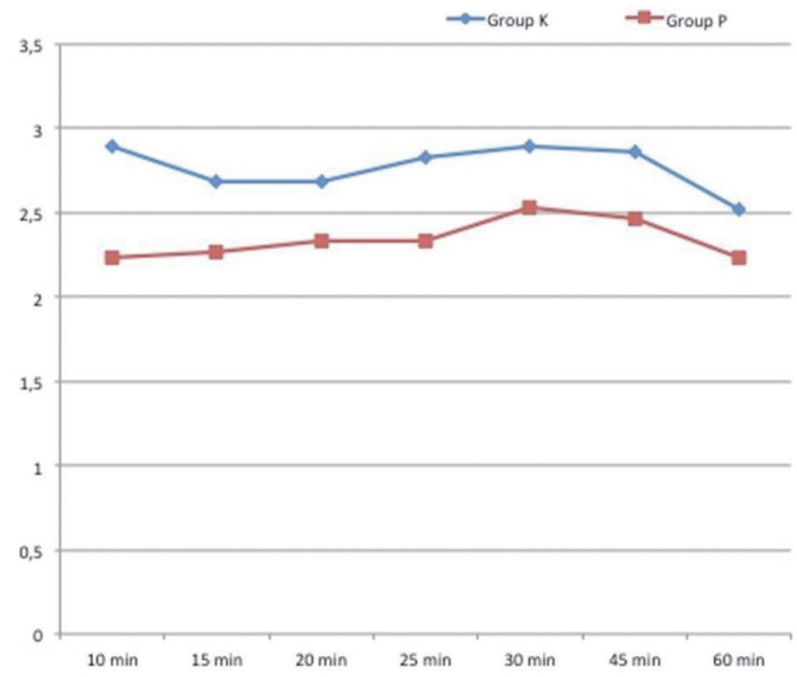

Figure 4. VAS values of the groups

\section{DISCUSSION}

This study detected better hemodynamic stability and less need for additional anesthetic doses in the Group P. No significant difference in the VAS was observed between the groups. This effect was likely related to the additional dose of fentanyl given in the propofol group. Adverse effects included nausea in 2 patients and hallucination in 2 patients in the Group K. Patients desire to feel no pain during and after curettage and to not remember the procedures, and physicians desire to work comfortably.

Propofol is frequently used in induction and maintenance anesthesia in intensive care or minor surgical interventions. Propofol has some side effects such as ventilation problems, decreased $\mathrm{O}_{2}$ saturation, and a risk of cardiac depression, particularly in patients with poor ventricular function. However, propofol exhibits rapid induction, deep anesthesia and antiemetic effects [6]. Propofol is preferably administered as an infusion to reduce its side effects but may also be applied in intermittent small doses. Ketamine is a non-barbiturate dissociative anesthetic agent that has been used for a long time. Ketamine, when given in a single IV dose, provides an anesthetic effect that begins at $30 \mathrm{sec}$, continues for 5-10 min and completely resolves in 1-2 hours [7]. Ketamine exhibits different 
effects from other IV anesthetic agents. Ketamine stimulates the cardiovascular system and increases the HR, BP, and systemic vascular resistance; importantly, however, these cardiovascular system and respiratory depressor effects may also increase with an increased dose. Ketamine is quite effective for sedation [8]. Combinations of anesthetic agents are used particularly in painful and invasive interventions. The combination of propofol and ketamine provides a more stable hemodynamic profile than propofol or ketamine used individually. Ketamine use with propofol has gained popularity because ketamine increases the analgesic effect and reduces the side effects of propofol because it is used in lower doses. Sub-dissociative doses of ketamine for analgesic purposes were safer than fentanyl in an interventional procedure study [9].

The hypotensive effect of propofol is related to the impairment of the baroreflex mechanism and sympathetic inhibition [3]. A study comparing propofol-fentanyl and propofol-ketamine combinations in pediatric patients undergoing upper gastrointestinal system endoscopy demonstrated that propofolketamine provided better hemodynamic stability [9]. Another study comparing the use of propofol, ketamine, and etomidate during curettage procedures observed more hypotension and bradycardia in patients in the propofol group [10].

Badrinath et al. used different doses of propofol-ketamine combinations in monitored anesthesia in female patients undergoing breast biopsy and did not encounter any severe airway problems [11]. However, in another study, apnea was observed in $60 \%$ of patients in the propofol group but not in the ketamine group [10]. In our study, the patients had encountered airway problem and the $\mathrm{SpO}_{2}$ did not decrease below $90 \%$ and oxygen was not required.

Tosun et al. observed that additional doses were not required in the ketamine-propofol group, but additional doses were required within the first minutes in the propofol-fentanyl group [9]. Akın et al. found that the need for an additional dose was less common in the propofol-ketamine group compared with the propofol-fentanyl group [12]. In the current study, additional dose requirements were less common in the propofol group, similarly to the above-mentioned study.

Evaluations of side effects revealed postoperative nausea and vomiting in $15 \%$ of patients in the propofol-ketamine group but in none of the patients in the propofol-fentanyl group [9]. Bardrinath reported that postoperative nausea and vomiting and psychomimetic side effects increased when the ket- amine dose used in combination increased [11]. Iskender et al. observed that $13.3 \%$ of patients in the ketamine group experienced nausea and vomiting [10]. The nausea and vomiting were not observed in any of the patients who received propofol in our study because of the antiemetic effect of propofol, but nausea was detected in two patients in the ketofol group. Additionally, hallucination was detected in 2 patients in the ketofol group.

A study comparing pain scores and analgesic consumption demonstrated that these values were significantly lower in the ketofol group [13]. Nejati et al. found lower VASs in the ketofol group compared with the midazolam-fentanyl group [14]. No differences in VASs were found between the ketofol and propofol groups in our study. This effect was related to the additional fentanyl given in the propofol group, which changed the VAS and eliminated the difference.

In conclusion, Ketofol anesthesia is a good option in the uterine curettages, which are outpatient procedure performed in gynecologic and obstetric practices, because the patients recover quickly and because it both comfortably provides sufficient analgesia for the minor surgical intervention and reduces complications.

\section{REFERENCES}

1. Reves JG, Glass PSA, Lubersky DA. Nonbarbiturate Intravenous Anesthetics. In: Miller RD., (ed) Anesthesia. USA: Churchill Livingstone; 2000. p. 249-256.

2. Haas DA, Harper DG. Ketamine: a review of its pharmacologic properties and use in ambulatory anesthesia. Anesth Prog 1992;39:61-68.

3. Messenger WD, Murray EH, Dungey PE, et al. Subdissociative-dose ketamine versus fentanyl for analgesia during propofol procedural sedation: A randomized clinical trial. Acad Emerg Med 2008;15:877-886.

4. Uğur B, Sen S, Oğurlu M, et al. Comparison of remifentanil-propofol and fentanyl-propofol combination for probe curettage. Turkiye Klinikleri J Gynecol Obst 2007;1:30-36.

5. Buppasiri P, Tangmanowutikul S, Yoosuk W. Randomized controlled trial of mefenamic acid vs paracervical block for relief of pain for outpatient uterine curettage. J Med Assoc Thai 2005;88:881-885.

6. Eker H, Cok OY, Ergenoglu P, et al. IV paracetamol effect on propofol-ketamine consumption in paediatric patients undergoing ESWL. J Anesth 2012;26:351356.

7. Green SM, Rothrock SG, Lynch EL, et al. Intramuscular Ketamine for Pediatric Sedation in the Emergency Department: Safety Profile in 1,022 Cases. Annals Emerg Med 1998;31:688-697. 
8. Rossi MG, Candiotti KA. New modalities and paradigms for sedation: "new sedation agents". Techniques in Gastrointestinal Endoscopy 2009;11:171-176.

9. Tosun Z, Yesmaoglu A, Coruh A. Propofol-ketamine vs propofol-fentanyl combinations for deep sedation and analgesia in pediatric patients undergoing burn dressing changes. Pediatr Anaesth 2008;18:43-47.

10. Iskender A, Erbaş M, Karagöz I. The comparison of tecniques of different sedo-analgesia in the outpatient gynaecologic operations. Med J Kocaeli 2012;3:5-10.

11. Badrinath S, Avramov MN, Shadrick M, et al. The use of a ketamine-propofol combination during monitored anesthesia care. Anesth Analg 2000;90:858-862.
12. Akin A, Esmaoglu A, Guler G, et al. Propofol and propofol-ketamine in pediatric patients undergoing cardiac catheterization. Pediatr Cardiol 2005;26:553-557.

13. Mortero RF, Clark LD, Tolan MM, et al. The effects of small-dose ketamine on propofol sedation: respiration, postoperative mood, perception, cognition, and pain. Anesth Analg 2001;92:1465-1469.

14. Nejati A, Shariat R, Ashraf H, Labaf A. Ketamine/ propofol versus midazolam / fentanyl for procedural sedation and analgesia in the emergency department: A randomized, prospective, double-blind trial. Acad Emerg Med 2011;18:800-806. 